\title{
Role of social workers to support single mothers: A case study of welfare receivers in Iran
}

\author{
Mohammad Reza Iravani*
}

Department of Social Work, Islamic Azad University, Khomeinishahr Branch, Daneshjou Blvd, Iran

\begin{tabular}{|c|c|}
\hline A R T I C L E I N F O & A B S T R A C T \\
\hline $\begin{array}{l}\text { Article history: } \\
\text { Received June 5, } 2011 \\
\text { Received in Revised form } \\
\text { August, } 3,2011 \\
\text { Accepted } 5 \text { August } 2011 \\
\text { Available online } \\
6 \text { August } 2011 \\
\text { Keywords: } \\
\text { Single mother } \\
\text { Empowering } \\
\text { Welfare impact } \\
\text { Audacity and empowering } \\
\text { Social activity }\end{array}$ & $\begin{array}{l}\text { The women who lose their partners normally face tremendous challenges among their parents } \\
\text { and in society. Women may lose their husbands for different reasons such as divorce, drug } \\
\text { addiction, violence and migration. They may often look to build a new life very quickly but will } \\
\text { find out that society does not treat them, properly. It is more difficult to find job and even a job } \\
\text { opportunity does not provide sufficient pay. In this paper, we study the impact of different } \\
\text { affecting parameters on empowering single mothers such as audacity, social responsibility, } \\
\text { trouble shooting, flexibility, stress tolerance, etc. We choose } 200 \text { single mothers who receive } \\
\text { welfare from the government of Iran and distribute a questionnaire among them based on four } \\
\text { different questions associated with social, economical, feeling and empowering. The results } \\
\text { indicate that audacity and social responsibility are the most important items while being } \\
\text { optimistic, independent and flexibility are counted as having the least impact on empowering } \\
\text { single mothers. }\end{array}$ \\
\hline
\end{tabular}

(C) 2012 Growing Science Ltd. All rights reserved.

\section{Introduction}

The women who lose their partners normally face tremendous challenges in society. They may lose their husbands for different reasons such as divorce, drug addiction, violence and migration and may often look to recover their lives very quickly but will soon find out that they must overcome to many challenges such as handling their children on their own, feeding the family and paying lots of bills. The society does not look at a single mother as previously and, in some countries, it is difficult to recover a previously lost life, very easily. There are various studies on how to empower the single mothers to increase their abilities and skills to help them manage their lives. The studies mostly look for the impact of different parameters on empowering single mothers such as audacity, social responsibility, etc.

Sun and Li (2009) studied whether the effects of parental divorce on adolescents' academic test performance vary by sibship size. They observed that interactions on adolescents' academic

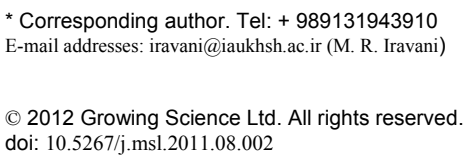


performance were completely described by differentiation in parental financial, human, cultural, and social resources.

Wickrama et al. (2006) investigated changes in family financial conditions and the physical health of married and recently divorced mothers. They studied on how divorce followed by single parenthood undermines the long-term physical health of rural mothers using four waves of survey data collected in Iowa, USA from 336 married and 80 divorced mothers during a 10-year period and they reported that single-parenthood creates financial difficulties for rural mothers. In addition, this financial adversity was linked to self-assessed physical health trajectories, which could contribute to change in morbidity. Divorce is one of the most important factors of chronic stress at midlife. According to Goldstein (1999), nearly half of all marriages in the USA end in divorce. Johnson and Wu (2002) reported that divorce has both mental and physical health consequences.

$\mathrm{Wu}$ and Hart (2002) studied the effects of marital and non-marital union transition on health and reported similar results. Taylor et al. (2010) studied life stress, maternal optimism, and adolescent competence in single mother. They emphasized on positive impacts of divorce among women who divorced in African American society and highlighted the need for further studies of processes and resources, which promote positive outcomes for African American mother-headed families and single mother families in general.

$\mathrm{Wu}$ and Eamon (2011) investigated the effects of involuntary unemployment and underemployment in single-mother families. They used 2004 panel of the survey of income and program participation (SIPP) to investigate patterns and correlates of unemployment and underemployment among singlemother families and reported substantial employment problems. Based on their results, although approximately one-half $(55.6 \%)$ of the single mothers had adequate employment, $30 \%$ experienced unemployment or involuntary job gaps, and approximately $15 \%$ experienced underemployment. The results also indicated that age, education level, past work experience, and homeownership were related to a reduced risk of employment problems. While, work disability, other family income, receipt of cash benefits, and state unemployment rates place single mothers at an increased risk of unemployment and underemployment. The findings suggested social policy implications and targeted assistance for those at-risk single mothers trying to secure adequate employment.

Noonan et al. (2007) examined the impact of welfare reform, labor market conditions, and the earned income tax credit (EITC) on the employment of black and white single mothers. They reported that during the period of economic expansion, increases in the EITC were the most important factor, accounting for approximately $25 \%$ of the increase in employment for both black and white single mothers. Declines in the unemployment rate and welfare reform were less important, together accounting for an additional $25 \%$ of the increase.

Frish and Zussman (2008) presented a study on the effect of transfer payments on the labor supply of single mothers. They reported that following the enactment of the law the labor supply of uneducated single mothers fell by about $10 \%$, due to a decrease in the employment rate and working hours but, from an economic perspective, the impact of the law on the labor supply of single mothers was not significant. The tax and welfare benefits, which provide income to single mothers, have changed dramatically in recent years. These changes began as far back as the mid-1980s and these tax and welfare changes have sharply increased the employment of single mothers and cut welfare regulations. Meyer and Sullivan (2004) studied the impacts of welfare and tax reform for the material well-being of single mothers in the 1980s and 1990s.

In this paper, we study the existing challenges among single mothers who live in a city of Esfahan, Iran. The present investigation attempts to assess the existing challenges women face and possible suggestions on empowering the single mothers to reach a better life style. The presentation of this 
paper first presents the structure of the research in section 2 and the details of our findings are given in section 3. The paper concludes the contribution of the paper in section 4.

\section{The proposed study}

One of the responsibilities of most countries' officials is to provide support for single mothers through establishing special organizations. These organizations are responsible to provide aid and special supports to empower single mothers. The support activities include welfare fees, training and consultation. There are literally four groups of single mothers, who divorce from their partners as follows,

- Drug addictions: When a person is addicted to drugs, he cannot continue normal relationship with his wife nor can he provide financial support for his family. In such circumstances, most mothers prefer to raise their children away from the consequences of drugs and violence.

- Widows: Many single mothers lose their partners in different forms of accidents, decease, etc. In such case, the family may not have financial support and need to receive temporary care from the government so that they would be empowered.

- Divorced: Many women prefer to separate from their partners when there are lacks of faiths, love and they face violence from their partners. In such cases, they prefer to live with their children away from their partners simply by divorcing their partners.

- Immigration: There are many cases, where the husband needs to travel to another city or country and cannot provide support for his family (Boot, 1995).

During the past decade, there have been several economical turmoil incidents in global economy. From the infamous incident of September, 11 to recent real state chaos started in United States, the negative consequences have influenced many people round the world. People have lost their jobs and faced with lots of bills, which need to be paid. As a result, the rates of single mothers are growing in the world and more women have needed social and economical support.

In Iran, when women get divorced, the society may look at these people differently. They are not normally welcome to their parents' home and it is more difficult for them to find jobs especially when they are supporting some children at various ages. The problem somehow becomes more complicated in small cities when most people know each other's. Drug dealers may target these women and there are some cases where they are involved in prostitution activities. These issues not only hurt single mothers but also jeopardize their children's futures. The children who become familiar with such bad experiences may wish to retaliate from the society and some of them are involved in crime activities. Therefore, this could motivate governments to support single mothers to raise their children hoping that the new generation would immune from their parents' bad experiences.

In this paper, we study the impact of four independent variables of economical, social, sentimental and empowering single mothers on 200 single mothers who receive welfare from the local agency located in the city in year 2010 and they all lived with their children. The questionnaire consists of 31 questions based on the four features in terms of social, economical, sentimental and empowering skills and they are all divided into Likert scale (Likert, 1932).

\section{The results}

The first observation of our survey about the single mothers who participated in our survey indicates that 17 percent of them have no education, 45.5 percent either finished their high school or they have 
2 years college education and the rest of them had 4-year university education or more. Note that most of these people were young people with one or two children, which shows an increase rate of divorce among people. The survey shows that 35.5 percent of the single mothers have less than five years of job experience, 34 percent had between five to ten years of job experience and 30.5 percent had more than ten years of job experience. Note that the welfare pay in Iran only covers a small portion of single mothers' costs and they must work to cover all their living expenses.

The other question of our survey is to concern whether they have finished living skills program or not. According to our survey, over 75 percent of the people took part in such programs and less than 25 percent of the people did not attend such program. The primary objective of these courses is to help single mothers increase their skills and to work and receive affordable income. The Pearson correlation between single mothers' audacity and empowering them indicates that there is a positive relationship between these two variables when the significance level is 0.01 . The other observation from our survey is that there is meaningful relationship between social responsibility and empowering single mothers when the significance level is 0.05 . Note that the Person correlation between these two variables also indicates a positive relationship. We did not find any meaningful relationship between two variables of empowering and flexibility and stress tolerance. In addition, being optimistic does not necessarily lead to empowering single mothers.

In terms of single mothers' general skills, our survey indicates that audacity and social responsibility are the most important items with an average of 73.82 and 61.42 , respectively. While being optimistic, independent and flexibility are accounted with an average of 34.71, 36.26 and 38.52, respectively.

In terms of diversity, flourish inspiring, being independence and responsible maintain the highest variances of $98.40,98.40$ and 83.17 , respectively. In addition, interpersonal relationships, tolerating stress and flexibility maintain the minimum variances of $46.51,50.98$ and 46.51 , respectively. We have performed a linear regression between the empowering as a function of four independent variables and the result yields $R^{2}=0.56$. In addition, ANOVA test result gives $\mathrm{F}=5.78$ with $\mathrm{P}$-value $=$ 0.000 , which means there is a meaningful relationship between empowering variable and personal under the confidence of 95 percent. Note that the regression analyze does not confirm any meaningful relationship between empowering and being optimistic or idealistic.

Our survey indicates valid t-student results for some parameters such as audacity, trouble shooting, flexibility, self-reliance and self-flourishing since the correlation ratio between these variables and empowering single mothers are $0.1,0.12,0.12,0.13$ and 0.10 , respectively, which indicates a meaningful relationship between these variables and empowering single mothers.

In order to see whether there are any differences among the working skills variables and empowering single mothers, we perform ANORA test. The results indicate that the F-values between single mothers' skills and their types are meaningful, which means that there is a different among the contribution of each working skills variable. The results of HSD test also indicate that the impact of trouble-shooting maintains a higher score than other working skills variables. In addition, the average number for self-working skills is more than the average number for being optimistic and being realistic. Finally, the average number for flexibility is more than being responsible in society and concurring.

We have performed a two-way t-student test between the independent variables and the results of $t$ student values for audacity, social responsibility, trouble shooting, flexibility, stress tolerance, being realistic, being optimistic, being independent, impulse control, self flourishing, inter-relationship skills and overall concurring were 5.8, 7.16, 4.6, 4.86, 7.13, 6.72, 6.43, 5.73, 6.19, 6.44 and 6.03, respectively, which are meaningful under 0.01 significance level. A regression analysis also indicates 
that there is a meaningful relationship between trouble shooting skills and empowering with a correlation value of 0.15 .

Based on the results we received in this survey, we can conclude that training plays an important role on increasing single mothers' skills. Therefore, it is suggested that regional government spend more training programs to help single mothers upgrade their skills. The other effort is to help single mothers setup small businesses by granting loans and facilities. The other important issue is that the welfare money given to single mothers does not cover their expenses. As a result, children of these families need to work and this could create serious problems in future. The government must make sure that the children are financially supported and they are encouraged to continue their education. The other important issue is to help single mothers' family increase their social activities by inviting them to participate to some social activities, actively.

\section{Conclusion}

In this paper, we have studied the impact of different affecting parameters on empowering single mothers such as audacity, social responsibility, trouble shooting, flexibility, stress tolerance, etc. The present study chose 200 single mothers who receive welfare from the government of Iran and distributed a questionnaire among them. The questionnaire contained different questions in terms of social, economical, feeling and empowering skills. The results have indicated that audacity and social responsibility are the most important items while being optimistic, independent and flexibility are counted as having the least impact on empowering single mothers. The proposed study has found that single mothers receive negligible amount of welfare, which could not help them manage their expenses. As a result, in many cases, both single mothers and their children need to work, which create serious problems for future generation. The study emphasizes that the government needs to increase the welfare and help them increase their abilities to empower them.

\section{Acknowledgment}

The present study was financially supported by a grant awarded by Islamic Azad University and the author would like to thank the officials for the financial support.

\section{References}

Boot, M. Z. (1995). Children of migrant fathers, the effects of father absence on Swazi children's preparedness for school. Journal of Comparative Educational Review, 39(2), 195-207.

Frish, R., \& Zussman, N. (2008). The effect of transfer payments on the labor supply of single mothers. Journal of Socio-Economics, 37(2), 627-643.

Goldstein, J. R. (1999). The leveling of divorce in the United States. Demography, 36, 409-414.

Johnson, D. R., \&Wu, J. (2002). An empirical test of crisis, social selection, and role explanations of the relationship between marital disruption and psychological distress: A pooles timeseries analysis of four-wave panel data. Journal of Marriage and Family, 64, 211-224.

Likert, R. (1932). A Technique for the Measurement of Attitudes. Archives of Psychology, 140, 1-55.

Meyer, B.D., \& Sullivan, J. X. (2004). The effects of welfare and tax reform: the material well-being of single mothers in the 1980s and 1990s. Journal of Public Economics, 88(7-8), 1387-1420.

Noonan, M. C., Smith, S.S., \& Corcoran, M. E. (2007). Examining the impact of welfare reform, labor market conditions, and the Earned Income Tax Credit on the employment of black and white single mothers. Social Science Research, 36(1), 95-130.

Sun, Y., \& Li, Y. (2009).Parental divorce, sibship size, family resources, and children's academic performance. Social Science Research, 38(3), 622-634. 
Taylor, Z. E., Larsen-Rife, D., Conger, R.D., Widaman, K.F., \& Cutrona, C. E. (2010). Life stress, maternal optimism, and adolescent competence in single mother, African American families. Journal of Family Psychology, 24(4), 468-477.

$\mathrm{Wu}, \mathrm{Z}$., \& Hart, R. (2002). The effects of marital and nonmarital union transition on health. Journal of Marriage and Family, 64, 420-432.

Wu, C.F., \& Eamon, M. K. (2011). Patterns and correlates of involuntary unemployment and underemployment in single-mother families. Children and Youth Services Review, 33(6), 820-828.

Wickrama, K.A.S., Lorenz, F.O., Conger, R.D., Elder Jr., G.H., Abraham, W.T., \& Fang, S.A. (2006). Changes in family financial circumstances and the physical health of married and recently divorced mothers. Social Science \& Medicine, 63(1), 123-136. 